\title{
Editorial
}

\section{Mind the gap}

Without any doubt a good LIS educational system is crucial for the academic world as well as for the professional world. But frequently in many countries LIS educational and research centers occupy one side of the field, with the professional world on the other. Thus, each sector usually discusses issues separately. In an attempt to reduce the gap between the two sectors, a joint EBLIDA and EUCLID committee decided to get people from both these worlds together at a European conference.

This special issue of Education for Information contains a selection from the papers presented at Librarian@2010 - Educating for the future, the conference held in Lisbon on 19-21 September 2007. It marks the first public event promoted jointly by EBLIDA and EUCLID. The local organizer of the meeting was the Associaça ão Portuguesa de Bibliotecários, Arquivistas e Documentalistas (http://www.apbad.pt/), or in English translation, the Portuguese Library, Archives and Information Professionals Association (also known as BAD), an association that is very interested in promoting fruitful discussions on the formal education of librarians, archivists and documentalists.

EBLIDA is the European Bureau of Library, Information and Documentation Associations. This small and efficient lobby organization is an independent umbrella organism representing national library, information, documentation and archive associations and institutions throughout Europe. Meanwhile, EUCLID, the European Association for Library \& Information Education and Research, promotes cooperation within library and information education and research centers.

The joint EBLIDA \& EUCLID committee announced, in their call for paper, that:

"There is a need to bridge the gap between the academic field and the field of practice when discussing the future of European library and information science education, the profession and its services. This conference aims to bring educators, researchers and practitioners together in order to discuss the effects of profound social changes related to digitization, multiculturalism and the growth of the knowledge economy. The conference will also consider the impact of the Bologna process, both in the arena of education and research and also in professional practice, and the relationship between the two".

The three main topics of the event were:

1. "Cooperation between academia and practice"

2. "Mobility and flexibility" 
3. "The role of academia and LIS associations in the continuous training of library professionals".

The members of the Organizing committee were Ragnar Audunson (EUCLID), Andrew Cranfield (EBLIDA), Pedro Hípola (EBLIDA), Marion Huckle (EBLIDA), Helena Patricio (BAD \& EBLIDA) and Annamaria Tammaro (EUCLID). David Bawden (EUCLID) and Miha Kovacs (EUCLID) were also collaborators in the process of reviewing the 32 paper proposals received.

We would like to take this opportunity to express our thanks to all the members of the BAD staff, especially to its president, António José de Pina Falcão; and to José Manuel Félix Correia and Sandrine Laurence Vercaempt, for a job well done.

The full programme of the conference and the PowerPoint presentations of all the papers can be found at: http://www.apbad.pt/Librarian@2010/Librarian@2010.htm.

It was indeed a good conference, the beginnings of a bridge to span a gap that still remains ...

Pedro Hípola

Facultad de Comunicación y Documentación

Campus de Cartuja

Universidad de Granada

E-18071 Granada

Spain

http://www.ugr.es/local/phipola 